International Journal of Social Sciences and Humanities
Available online at http://sciencescholar.us/journal/index.php/ijssh
Vol. 2 No. 3, December 2018, pages: 86 94
e-ISSN: 2550-7001, p-ISSN: 2550-701X
https://doi.org/10.29332/ijssh.v2n3.204

\title{
Social Media as Promotion Trend for Increasing Tourist Visit towards Digital Era
}

\author{
CrossMark \\ Anak Agung Gde Alit Geria ${ }^{a}$, A.A. Istri Agung Maheswari ${ }^{\text {b }}$, A. A. Gde Putra Pemayun ${ }^{\text {c }}$ \\ Article history: Received 3 April 2018, Accepted: 30 August 2018, Published: 8 October 2018
}

\section{Correspondence Author ${ }^{\text {a }}$}

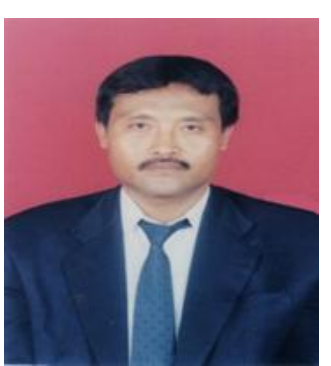

Keywords

Browser;

Marketing intelligence

system;

Promotion trend;

Social media;

Tourist visit;

\begin{abstract}
This study examines "Social media as a trend of promotion for increasing tourist visits of the digital era at Tegallantang village Ubud Bali". Marketing leaders need timely and accurate reports about current sales. Smart companies make use of "cookies," records of Web site users that are stored in a personal browser, are smart target marketing users. Companies must translate sales data carefully so as not to draw wrong conclusions. In addition to saving mail expenses, this data manipulation can often achieve a double-digit response rate. The company stores this data (data warehousing) and makes it easily accessible to decision makers. Furthermore, by employing analysis that has expertise in complex statistical methods, companies can "dig" data (data mining) and gather new knowledge about neglected customer segments, and other useful information. The internal data system provides results data, but the marketing intelligence system provides current data (happenings). Marketing intelligence system (marketing intelligence system) is a collection of procedures and resources used by managers to obtain daily information about various developments in the marketing environment. The marketing manager collects marketing intelligence by reading books, newspapers, and trade publications, talking with customers, suppliers, and distributors; observe "social media" on the internet through online discussion groups, e-mail lists, and blogs and meet with other company managers. In this context, social media plays an important role for every effort to connect with digital customers spread across the world indefinitely.
\end{abstract}

e-ISSN: 2550-7001, p-ISSN: 2550-701X ๑Copyright 2018. The Author. SS Journals Published by Universidad Técnica de Manabí. This is an open-access article under the CC BY-SA 4.0 license (https://creativecommons.org/licenses/by-sa/4.0/) All rights reserved.

a University of Education National, Indonesia

b University of Education National, Indonesia

c University of Education National, Indonesia 


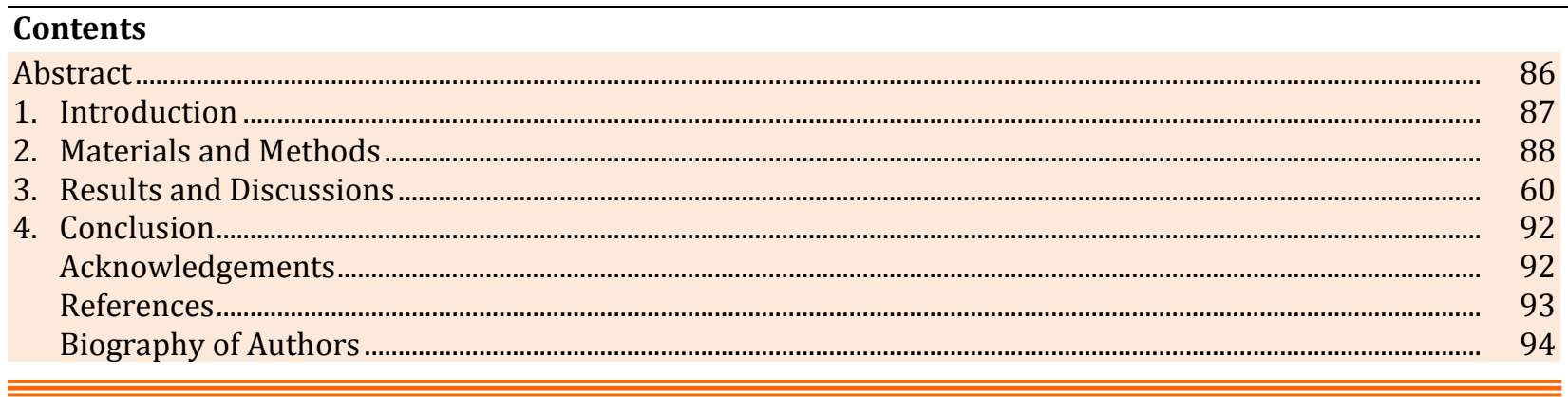

\section{Introduction}

Creating loyal customers is at the core of every business (Don Peppers and Martha Rogers, 2017). The only value that is created by the company is the value that comes from the customer, including all the values that are owned now and the value that will be owned in the future. A business is called success if it is successful in getting, maintaining, and growing customers. Customers are the only reason the company makes factories, employs employees, schedules meetings, makes fiber-optic lines, or engages in any business activity. Without customers, you will not have a business. The managers who those believe, the customers are the only profit center. A successful marketing manager that is turning the diagram with the top of the pyramid there is a customer, the next order is frontline people who fulfill, serve, and satisfy customers; underneath there are middle managers, whose job is to support front-line people so that they can serve good customers and at the base of pyramids is top management whose job is to employ and support good middle managers. Some companies are established with business models in which customers are placed above, and customer advocacy has become a strategic and competitive advantage. With the emergence of digital technologies such as the internet, consumers who are getting smarter today expect companies to do more than just connect with them, more than just satisfying them, and even more than just pleasing them. Today consumers are more educated and more knowledgeable. They have the means to verify company claims and look for alternatives that are superior. The value perceived by the customer is the difference between the prospective customer's assessment of all the benefits and costs of an offer against the alternative. Total customer benefits are the monetary value of the collection of economic, functional, and psychological benefits that customers expect from a market offer that is caused by products, service personnel, and the image involved. Then the perceived value of the customer is based on the difference between what the customer gets and what he gives to the possibility of different choices. Customers get benefits and bear the costs. Marketers can increase the value of customer offers through a combination of increased economic, functional, or emotional benefits and reduce one or more types of costs. Based on the above phenomena, the following issues can be formulated (1) What is the role of social media as a promotion trend for increasing tourist visits of the digital era at Tegallantang village Ubud Bali? (2) What is the impact of social media as a promotional trend to increase tourist visits at Tegallantang village Ubud Bali? (3) Is the implementation of social media as a promotion trend for increasing tourist visits can be understood by local tour operators in the village of Tegallantang Ubud Bali?

\section{Literature Review}

Research from Ijey (2016) with the title "Promotion strategies through appropriate and effective social media" Many people think of promoting online content as simple as publishing posts and doing social media marketing in various social media channels. However, in fact, a promotional strategy is needed through social media that is planned and in accordance with the business that is done so that the results are effective. There are various kinds of social media used in Indonesia, and this is not a secret. However, which social media is suitable for increasing blog visitors. Use only two types of social media in promoting blogs or even using one type. Because many have tried to promote their blogs in all social media channels, but the result is that interactions only occur on certain social media. Therefore, to be able to determine which social media has the potential to be the choice, do two steps, namely (1) Get to know the reader, that is to understand the type of

Geria, A. A. G. A., Maheswari, A. I. A., \& Pemayun, A. A. G. P. (2018). Social media as promotion trend for increasing tourist visit towards digital era. International Journal of Social Sciences and Humanities, 2(3), 86-94. https://doi.org/10.29332/ijssh.v2n3.204 
each social media and the character of each user, the most important thing is to understand the target audience of the blog reader. Google Analytics can be one tool that helps identify age, gender, interest and other important things about blog readers. Then complete the data by learning the types and roles of social media that are right for business. From these data, it will be easier to determine which type of social media is suitable for promotional strategies through social media for business. 2) Determine the potential of each social media. The results of the study by Simon Kemp from We Are Social (2016) resulted in the following sequence of the most active social media in Indonesia: Facebook, Google+, Twitter, Instagram, Pinterest. The results of the above studies are very helpful in seeing active social media channels in Indonesia. However, you must think back to who the target audience is. In this context, the role of social media influences all promotions according to the company being run and the expertise that marketers have to get sympathy from consumers.

Next research from Thackeray, et al., (2008), with the title " Enhancing promotional strategies within social marketing programs: use of Web 2.0 social media" The advancement of information technology in the globalization era made many changes. It cannot be denied that globalization, both directly and indirectly, has a positive and negative impact. The positive impacts of globalization include the increasingly sophisticated communication and information tools, the ease of acquiring knowledge, more practical shopping, and so on. However, these negative impacts include waning friendship, weakening traditional culture, losing the spirit of nationalism and patriotism, and the increasingly widespread social media user community. The general public has known social media and applied it in daily life. Social media varies in form, from Facebook, Instagram, Twitter, WhatsApp, BBM, and many more. Social media is a major factor in the lives of Indonesian people, especially for teenagers. Teenagers who do not have social media will feel embarrassed because they are not following the development of the world faster. Meanwhile, there are some teenagers who use social media only to show off or brag. There are still many among the good adolescents, adults, and parents who are not responsible for social media which ultimately has a negative impact on themselves. It's okay to use social media as long as you can be responsible. Therefore, use it properly and should. In this context, the role of social media has positive and negative effects depending on the users using it properly and correctly to minimize the impact. While this study examines social media as a promotion trend for increasing tourist visits in the digital era in the village of Tegallantang Ubud Bali (Amerta, el al., 2018).

\section{Materials and Methods}

The data used in this study included primary data, namely data, and information obtained directly from the source/respondent. This data was obtained by conducting interviews with the community of Tegallantang village, Ubud Bali. By using proportional sampling technique with a sample of 8 people from entrepreneurs engaged in the tourism sector, 9 tourists and 13 people in the community. Secondary data, namely data and supporting information obtained from the village office of Tegallantang Ubud Bali.

\section{Research model specifications}

Analysis Kotler \& Armstrong's SWOT Theory in Rangkuti (2016), Analysis of Theory Strength, Weakness, Opportunity, Threats (SWOT) is used to analyze the potential and challenges of social media as a promotional trend to increase tourist visits in Tegallantang Village, Ubud, Bali. SWOT analysis is a systematic factor for formulating a strategy. This analysis is based on the logic that can maximize strengths (opportunities) and opportunities but simultaneously can minimize weaknesses (weaknesses) and threats (threats). The process of strategic decision making is always related to the taking of mission, goals, strategies, and policies for companies engaged in tourism. SWOT analysis compares the external factors of opportunities and threats with internal factors of strengths and weaknesses (Rangkuti, 2016). This analysis is principally a strategy that produces strong harmony between internal capabilities and external situations. According to the stages of preparation in strategic planning, are 1) the stages of data collection; 2) analysis phase; 3) decision-making stage. 
Social Category Theory Melvin L. De Fleur (2016) Social category theory is a collection, group, or social categories that exist in society will provide a uniform response to exposure to social media. This is an association such as entrepreneurs in the tourism sector in the village of Tegallantang Ubud Bali, a social category in an urban-industrial society whose behavior when exposed to certain stimulants will be almost uniform. The basic assumption of social category theory is the theory that states that even though the life of modern society is heterogeneous, people who have a number of similar characteristics will have the same traditional lifestyle. Characteristics: age, sex, income, education, settlement, or religious relations. Style, orientation and behavior equation will relate to social media symptoms in uniform behavior.

\section{Research Location}

The location of this research is in the village of Tegallantang Ubud Bali by observing and mapping community activities in a measurable manner. The time of observation as an object of analysis is the condition of 12 (twelve) months from January to December of 2017. The consideration of the use of 2017 was taken to facilitate the recording of information on respondents, namely, entrepreneurs who move in the tourism sector, tourists and community of Tegallantang village Ubud Bali.

\section{Research Instruments}

The instruments used in this study were descriptive research through literature surveys and field surveys and in-depth interviews. Interviews conducted are open questions and closed questions end.

\section{Data Analysis Method}

The analytical method used in this study includes several methods in accordance with the research objectives are as follows:

1. Analysis Kotler \& Armstrong SWOT theory in Rangkuti (2016). Analysis Theory Strength, Weakness, Opportunity, Threats (SWOT) is used to analyze the potential and challenges of social media as a promotional trend to increase tourist visits in Tegallantang Village, Ubud, Bali. SWOT analysis is a systematic identification of various factors to formulate a strategy. This analysis is based on the logic that can maximize strengths (opportunities) and opportunities (opportunities) but simultaneously can minimize weaknesses (weaknesses) and threats (threats). The process of strategic decision making is always related to the taking of mission, goals, strategies, and policies for the companies engaged in tourism. SWOT analysis compares the external factors of opportunities and threats with internal factors strengths and weaknesses (Rangkuti, 2016), this analysis is principally a strategy that results in a strong harmony between internal capabilities and external situations.

Strength is a resource, skill, or other advantages associated with company competitors and market needs that can be served by companies that are expected to be served. Strength is a special competition that provides a competitive advantage for companies in the market. Weaknesses are limitations or lack of resources, skills, and capabilities that effectively inhibit the company's performance. These limitations can be in the form of facilities, financial resources, management skills, and marketing skills which can be a source of corporate weakness. Opportunities are important situations that are advantageous in the corporate environment. The tendency - an important tendency is one of the sources of opportunity, such as changing technology and increasing the relationship between the company and the buyer or supplier is an illustration of opportunities for the company.

The threat is an important situation that does not benefit the company environment. The threat is the main disturbance for the current or desired position of the company. The existence of new or revised government regulations can be a threat to the company's success.

2. Social Category Theory Melvin L. De Fleur (2010) Social category theory is a collection, group, or social categories that exist in the community will provide a uniform response to media exposure. This theory

Geria, A. A. G. A., Maheswari, A. I. A., \& Pemayun, A. A. G. P. (2018). Social media as promotion trend for increasing tourist visit towards digital era. International Journal of Social Sciences and Humanities, 2(3), 86-94. 
states that the existence of associations such as descendants of courtiers and communities of people living in the village of Tohpati Klungkung, a social category in an urban-industrial society whose behavior when exposed to certain stimulants will be almost uniform. The basic assumption of social category theory is a sociological theory which states that even though the life of modern society is heterogeneous, people who have a number of similar characteristics will have the same traditional lifestyle. Characteristics: age, sex, income, education, settlement, or religious relations. Style, orientation and behavior equation will relate to a symptom as in the mass media in uniform behavior. Members of a particular category will choose about the same communication, and respond in almost the same way. In this case, social media influences the way people relate to each other on an interpersonal level. Elements of the concept of self-awareness in social interactions between people such as (1) self-concept, namely how to look at oneself, usually this is done by classifying the characteristics of personal traits, characteristics of social characteristics, and social roles. (2) Personal characteristics are qualities possessed, at least in perception about yourself. These characteristics can be physical (male, female, high, low, beautiful, handsome, fat) or can also refer to certain abilities (smart, quiet, capable, stupid, educated) self-concept is closely related to knowledge. If one's knowledge is high, one's self-concept is high too. Conversely, if a person's knowledge is low, one's selfconcept is low too. (3) Social characteristics, namely the characteristics displayed in relationships with other people (friendly or cruel, extroverted or introverted, talkative or quiet, caring or indifferent)

\section{Observation and Interview Techniques}

Observations are made by observing directly on the field so that you can see and observe more closely the condition of the Tegallantang village in Ubud Bali. An in-depth interview is with several informants who have been assigned, 30 people.

\section{Documentation Study}

Documentation study, namely data collection techniques are taken several documents or past records in the Tegallantang Ubud Bali village office and the relevant agencies.

\section{Results and Discussions}

Analysis Kotler \& Armstrong SWOT theory in Rangkuti (2016), Analysis Theory Strength, Weakness, Opportunity, Threats (SWOT) is used to analyze the strengths, weaknesses, opportunities, and threats of social media as a promotional trend to increase tourist visits in the village of Tegallantang Ubud Bali. The function of the Swot analysis is to get information from the situation analysis and separate it in internal issues (strengths and weaknesses) and external issues (opportunities and threats). Hartline (2000), The SWOT analysis will explain whether the information indicates something that will help the company achieve its objectives or provide an indication that there are obstacles that must be faced or minimized to meet the desired income. SWOT analysis can be used in a variety of ways to improve analysis in business strategy setting. Generally what is often used is as a systematic framework/guide in the discussion to discuss basic alternative conditions that might be considered by the company.

Strengthening $(S)$ is an analysis of the strength, situation or condition that is the strength of an organization or company at this time in this regard (1) Support from the government through the existence of the Ministry of Tourism, (2) Devices of legislation as well as relevant Indonesian Government policies regional wide tourism (3) Potential owned by Tegallantang Ubud Bali (4) Availability of human resources (5) Having community-based tourist attraction (6) Having local cultural attractions, crafts and local food, (7) Having attraction artificial like a painting museum (8) Easy accessibility from the cities of Denpasar, Gianyar, Badung, Bangli and Karangasem (9) The status of the land is in the form of village land and owned by the residents so that it is easy to manage. 
Weaknesses (W) is an analysis of weaknesses, situations or conditions that are weaknesses of an organization or company at this time in this regard (1) Weak role and institutional community of Ubud Bali's Tegallantang village, especially communities around the area (2) Bureaucratic system that causes high economic costs (3) Issues of problems and conflicts within the region that are more prominent than the potential of the existing area (4) Weak scientific and technological support (5) Poor coordination, integration and synchronization between various sectors (6) Weaknesses human resources, in providing services to tourists who come from various countries with diverse languages (7) There is still a lot of tourism potential in the undeveloped Tegallantang village of Ubud Bali.

Opportunity (0) is an analysis of opportunities, situations, or conditions that are opportunities outside an organization or company and provide developing opportunities for the organization in the future. In this regard (1) Commitment of national and provincial policymakers to tourism development in Tegallantang Ubud Bali (2) International and national community commitment and support for sustainable tourism development (3) Support of local level community institutions towards tourism as an opening of employment opportunities (4) Potential investment in the tourism sector that quickly results (5) High tourist interest in cultural tourism activities (6) Development of family tourism markets that require tourism facilities and activities that will continue to increase.

Threats (T) is a threat analysis, a way to analyze challenges or threats that must be faced by a company or organization to deal with various kinds of unfavorable environmental factors in a company or organization that causes setbacks. In this case (1)

The high level of social vulnerability such as the income gap of the Tegallantang village of Ubud Bali and the migrants causing disturbance, (2) The low level of education of the people in Tegallantang village, Ubud Bali (3) The economic condition of the community which is still very dependent on tourist arrivals, if just a bit of turmoil in the country, there is a cancellation of visits (4) Very high land requirements, (5) Investment policies in the tourism sector are not attractive to investors (6) The carrying capacity of the environment is limited to the accumulation of larger tourism activities, which will impact on the decline in the quality of attraction of tourism itself.

From the above phenomenon, it can be said that the development of social media has succeeded in changing a new paradigm, namely encouraging trust through shared content. After the appropriate content, the next key is to build engagement, which is to ensure the published content reaches the audience with the right segmentation. Moses commented on the current trend of social media platforms, content is not displayed chronologically but is based on certain algorithms. In the context of SWOT analysis, every company or organization always have strengths and weaknesses as well as opportunities and threats, but if carefully examined and using social media all will be resolved well.

Social Category Theory Melvin L. De Fleur (2010). Social category theory is a collection, group, or social categories that exist in the community will provide a uniform response to exposure to social media. The existence of associations, social categories are in an urban-industrial society whose behavior when exposed to certain stimulants will be almost uniform. The relationship between social media and the people of Tegallantang Ubud Bali is described as an intervening variable between social media and behavior changes that occur between tourists and the community in the village of Tegallantang Ubud Bali. Another relationship between social media and the community of Desa Tegallantang Ubud Bali can be seen between the complementary roles between social media channels and Tegallantang Ubud Bali villagers and tourists when deciding to accept or reject innovation. The relationship between social media and the people of Tegallantang Ubud Bali can be seen in the socialization effects of social media. Social media is one source where people learn about the surrounding community. In this case, social media influences the way tourists and surrounding communities relate to each other on an interpersonal level. Elements of the concept of selfawareness in social interactions between people such as (1) self-concept, namely how to look at oneself, usually this is done by classifying the characteristics of personal traits, characteristics of social characteristics, and social roles. (2) Personal characteristics are qualities possessed, at least in perception about yourself. These characteristics can be physical (male, female, high, low, beautiful, handsome, fat) or can also refer to certain abilities (smart, quiet, capable, stupid, educated) self-concept is closely related to knowledge. If one's knowledge is high, one's self-concept is high too.

Conversely, if a person's knowledge is low, one's self-concept is low too. (3) Social characteristics, namely the qualities displayed in relationships with others (friendly or discouraged, talkative or quiet, attentive or

Geria, A. A. G. A., Maheswari, A. I. A., \& Pemayun, A. A. G. P. (2018). Social media as promotion trend for increasing tourist visit towards digital era. International Journal of Social Sciences and Humanities, 2(3), 86-94. 
indifferent, etc.). This affects the social role, which is everything that includes the relationship between tourists and people living in the village of Tegallantang Ubud Bali. (4) The social role, when social roles are part of self-concept, social relations are defined with other people, such as father, wife, or teacher. This social role can also be related to culture, ethnicity, or religion. (5) Multiple selves between tourists and people living in the village of Tegallantang Ubud Bali when they conduct various activities, interests, and social relations. When involved in interpersonal communication, have two selves in self-concept, such as perception of self, and perception of other people's perceptions of them. Sometimes the Tegallantang village of Ubud Bali can forget what is actually in itself like ethnic culture and others because this theory discusses the uniformity of a society even though the society is heterogeneous because, with this uniformity, a society will follow new rules, norms, culture, and others from the uniformity that has been created.

From the discussion above it can be said that the basic assumptions of social category theory are a sociological theory which states that although tourists and people living in Tegallantang village, Ubud, modern Bali are heterogeneous, people who have a number of similar characteristics will have the same traditional lifestyle. Characteristics: age, sex, income, education, settlement, or religious relations. Style, orientation and behavior equation will relate to a symptom as in social media in uniform behavior. Members of a particular category will choose about the same communication, and respond in almost the same way. This affects the social role, which is everything that includes the relationship between tourists and the community in the village of Tegallantang Ubud Bali. This theory is consistent that comes from general sociology regarding social media.

\section{Conclusion}

First, the SWOT Analysis Theory discusses Strength (S) in this case the support from the government through the existence of the Ministry of Tourism, the set of laws and regulations of the Government of Indonesia related to the expansion of regional tourism, the potential of Tegallantang Ubud Bali in the form of a green and flat expanse of land. Weaknesses (W) is the weak role and institution of the community of Ubud Tegallantang village, Bali, especially the people around the region, the bureaucratic system that causes high economic costs, issues of issues and conflicts within the tourism area that are more prominent than the potential of the existing area. Opportunity $(0)$ is the commitment of policymakers at the national and provincial levels towards the development of tourism in the village of Tegallantang Ubud Bali, the commitment, and support of the international and national community towards the development of sustainable tourism. Threats $(\mathrm{T})$ is an analysis in this case that there is still a high level of social vulnerability such as the income gap of the Tegallantang village of Ubud Bali and the migrants, causing disturbance, the economic condition of the people which is still very dependent on tourist arrivals, if there is only a little domestic turmoil visit cancellation. Second, the Social Category Theory of associations, social categories in urban-industrial societies whose behavior when exposed to certain stimulants will be almost uniform. The relationship between social media and community communication of the Tegallantang village of Ubud Bali is described as an intervening variable between social media and behavior changes that occur between tourists and the community in the village of Tegallantang Ubud Bali. If someone's knowledge is high, one's self-concept is high too. Conversely, if one's knowledge is low, one's self-concept is low.

\section{Acknowledgments}

The author would like to thank the reviewer for their consideration to the further process of the peer review. The author as well as thanks to the editor for their support, valuable time, and advice. Last but not least, the author thanks all researcher for their contribution as the references to the present article. 
References

Amerta, I. M. S., Sara, I. M., \& Bagiada, K. (2018). Sustainable tourism development. International Research Journal of Management, IT and Social Sciences, 5(2), 248-254.

DeFleur, M. L., \& DeFleur, M. H. (2016). Mass communication theories: Explaining origins, processes, and effects. Routledge.

Hartline, M. D., Maxham III, J. G., \& McKee, D. O. (2000). Corridors of influence in the dissemination of customer-oriented strategy to customer contact service employees. Journal of Marketing, 64(2), 35-50.

Ijey, N. 620. Ley General de las Aguas Nacionales.

Kemp, S. (2016). Digital In 2016. We are social's compendium of global digital, social, and mobile data, trends, and statistics. We are social.

Kotler, P., \& Armstrong, G. (2002). El concepto de marketing. P. Kotler, Dirección de marketing.

Peppers, D., \& Rogers, M. (2016). Managing customer experience and relationships: A strategic framework. John Wiley \& Sons.

Rangkuti, F. (1998). Analisis SWOT teknik membedah kasus bisnis. Gramedia Pustaka Utama.

Thackeray, R., Neiger, B. L., Hanson, C. L., \& McKenzie, J. F. (2008). Enhancing promotional strategies within social marketing programs: use of Web 2.0 social media. Health promotion practice, $9(4), 338-343$.

Geria, A. A. G. A., Maheswari, A. I. A., \& Pemayun, A. A. G. P. (2018). Social media as promotion trend for increasing tourist visit towards digital era. International Journal of Social Sciences and Humanities, 2(3), 86-94. https://doi.org/10.29332/ijssh.v2n3.204 


\section{Biography of Authors}

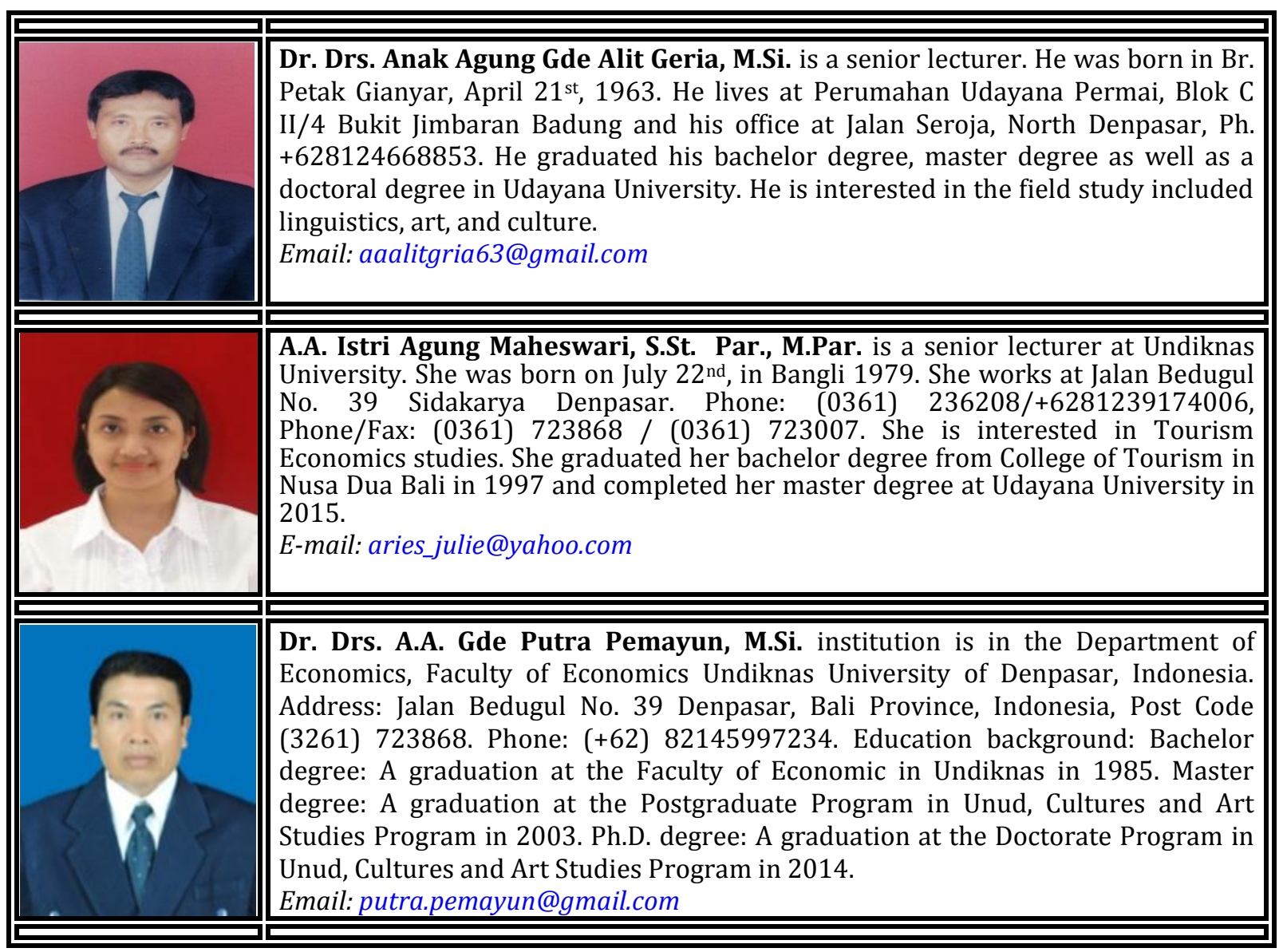

